\title{
EFFECTS OF A CHEMICAL PLANT GROWTH REGULATOR AND PLANTING DENSITY ON THE LEAF SENESCENCE AND YIELD OF SPRING MAIZE IN NORTHEAST CHINA
}

\author{
MenG, Y. - LIU, X. M. - GU, W. R. ${ }^{*}-$ WeI, S. ${ }^{*}$ \\ Department of Crop Cultivation and Farming System, College of Agriculture, Northeast \\ Agricultural University, 150030 Harbin, PR China \\ *Corresponding authors \\ e-mail: wanronggu@163.com,weishi5608@126.com; phone: +86-451-5519-0472
}

(Received 27 $7^{\text {th }}$ Sep 2019; accepted $4^{\text {th }}$ Feb 2020)

\begin{abstract}
The study aims to analyze the effects of chemical applications on the leaf senescence and yield of maize under different planting densities in Northeast China. Dongnong 253 (hybrid maize), was planted at four densities, i.e. 50,000, 60,000,70,000, and 80,000 plants ha ${ }^{-1}$. The leaves were sprayed with the plant growth regulator 'Yuhuangjin' (the main components of which include aminoacyl esters and ethephon) during the jointing stage. The results showed that the highest maize yield, i.e. $13290.95 \mathrm{~kg} \mathrm{ha}^{-1}$, was obtained when the plants were treated with 'Yuhuangin' and 70,000 plants ha ${ }^{-1}$. As the planting density increased in the water treatment, the height gradually increased, the dry weight of individuals decreased, and the barren stem proportion and lodging risk increased. In contrast, 'Yuhuangjin' reduced plant height, increased the dry weight of individual plants, and reduced both the barren stem proportion and the lodging risk. As planting density increased, the degree of reduction in leaf SPAD increased and the degree of leaf senescence increased in water. However, 'Yuhuangjin' increased leaf greenness and delayed senescence. During leaf senescence process, the activities of antioxidant enzymes (SOD, POD, CAT) decreased, the MDA content increased, and the soluble protein content decreased in the water treatment in response to increasing density. Compared to the water, 'Yuhuangjin' increased the activities of SOD, POD and CAT as well as the soluble protein content but reduced the MDA content. Under high planting densities, 'Yuhuangjin' have important values with respect to increasing maize yields and delaying leaf senescence during the late growth stage. This research provides a theoretical and experimental basis for maize production in Northeast China.
\end{abstract}

Keywords: maize, plant growth regulator, density, leaf senescence, yield, antioxidant enzymes

\section{Introduction}

Density is an important factor that determines maize yields (Ogunlela et al., 1988). The planting density of maize (Zea mays L.) in Northeast China is generally low, and increasing density is an important cultivation practice that can increase yields. Taking the United States as an example, maize planting density has been increasing since the 1960s, from 60000 plants ha ${ }^{-1}$ in the 1990 s to more than 70000 plants $^{-1} \mathrm{a}^{-1}$ at the end of the 20th century. At present, high-yield fields are generally about 100000 plants ha ${ }^{-1}$ (Lu et al., 2011; Xu et al., 2019). However, a planting density that is too high will reduce individual plant production, and improper control may even reduce yields (Andrade and Calvino, 2002; Shin et al., 2014; Ren et al., 2017; Tokatlidis, 2017). The key to achieving high yields involves the ability to increase the density and sustain reasonable yields of individual maize plants. Plant growth regulators can effectively control maize growth and development. Many studies have recently shown that plant growth regulators play positive roles in improving crop quality, shaping ideal phenotypes and increasing yields (Zhao et al., 2006a; Chen et al., 2013; Cao et al., 2016; Xu et al., 2017). The process of maize leaf senescence reflects the length of its 
functional period, which is directly related to yield production (Pommel et al., 2006). Therefore, research conducted on maize yield and senescence physiology under different planting densities and in response to the applications of plant growth regulators has important practical significance.

Within a certain range, maize yield increases with increasing density. As maize planting density increases, light transmission within the canopy decreases, senescence increases, the grain number per spike and the 100-grain weight decrease, and the lodging rate increases (Li et al., 2011; Cao et al., 2013). Planting density significantly affects the leaf area index, plant height, ear length, and number of grains per ear, grain weight per ear, 100-grain weight, biological yield and grain yield (Shafi et al., 2012). Population yield increases with increasing density within a certain density range, and rational close planting is an important cultivation practice for achieving high yields (Zhang et al., 2006). The grain yield of an individual maize plant decreases as the plant density increases, and competition for photosynthate may lead to ear and grain abortion during the flowering phase (Andraski et al., 2000; Andrade and Calvino, 2002).

Exogenous substances can accelerate the rate of protein synthesis in plants, increase enzymatic activity and promote other physiological processes. Studies conducted on various plants have shown that exogenous substances can increase antioxidant enzyme (superoxide dismutase (SOD), guaiacol peroxidise (POD), catalase (CAT)) activity during leaf senescence, reduce malondialdehyde (MDA) contents, and increase soluble protein contents and as well as the stay-green ability of plant leaves (Bajguz and Hayat, 2009; Pan et al., 2013). 'Yuhuangjin' is a plant growth regulator that was developed for maize; the regulator consists of an aminoacyl ester combined with ethephon. 'Yuhuangjin' can improve lodging resistance, enhance the stay-green ability of leaves, and increase both the photosynthetic rate and number of aerial root layers. This plant growth regulator has shown clear effects on generating ideal phenotypes and increasing the lodging resistance of maize (Diallo et al., 2015). The planting density of spring maize in the northeastern region of China is relatively low, and the yield potential has not been attained. Research on the application of 'Yuhuangjin' has focused on morphological indexes, investigations of physiological indexes related to yield increases are scarce.

In this experiment, we studied the yield and senescence process of maize during the late growth stage in response to both 'Yuhuangjin' treatment and different planting densities. The results from this study provide a theoretical and experimental basis for further rational application of 'Yuhuangjin' to spring maize in Northeast China.

\section{Materials and methods}

\section{Experimental materials and treatments}

The field experiments were performed at the Xiangfang Experimental Station of Northeast Agricultural University $\left(126^{\circ} 63^{\prime} \mathrm{E}, 45^{\circ} 44^{\prime} \mathrm{N}\right)$, Harbin, Heilongjiang Province, China, in 2014 and 2015. Dongnong 253 (compact growth habit, plant height of $280 \mathrm{~cm}$, ear height of $110 \mathrm{~cm}$ ) was used as the experimental material. The plant growth regulator 'Yuhuangjin' was provided by Fujian Haoluon Biology Engineering Technology Co. Ltd, China. The soil was previously planted with soybean and is classified as a chernozem ( $\mathrm{pH} 6.85$ ); the soil contained $25.25 \mathrm{~g} \mathrm{~kg}^{-1}$ organic matter, $1.7 \mathrm{~g} \mathrm{~kg}^{-1}$ total nitrogen $(\mathrm{N}), 179.35 \mathrm{mg} \mathrm{kg}^{-1}$ available potassium $(\mathrm{K}), 65.34 \mathrm{mg} \mathrm{kg}^{-1}$ available phosphorus (P), and $118.21 \mathrm{mg} \mathrm{kg}^{-1}$ alkaline $\mathrm{N}$. The monthly weather data, i.e. 
air temperature, precipitation, the number of sunshine hours and wind speed, measured at the experimental site during the maize growing season in 2014-2015 are shown in Table 1 .

Table 1. Daily mean values of weather variables measured at the experimental site during the maize growing seasons in 2014 and 2015

\begin{tabular}{c|cc|cc|cc}
\hline \multirow{2}{*}{ Month } & \multicolumn{2}{|c|}{ Mean temperature $\left({ }^{\circ} \mathbf{C}\right)$} & \multicolumn{2}{|c|}{ Precipitation $(\mathbf{m m})$} & \multicolumn{2}{c}{ Sunshine hours $(\mathbf{h})$} \\
\cline { 2 - 7 } & 2014 & 2015 & 2014 & 2015 & 2014 & 2015 \\
\hline April & 10.30 & 8.56 & 6.10 & 6.60 & 267.00 & 191.00 \\
May & 14.30 & 14.25 & 91.40 & 77.60 & 127.50 & 156.90 \\
June & 22.90 & 22.06 & 56.80 & 77.30 & 216.80 & 226.70 \\
July & 23.10 & 23.60 & 115.50 & 52.90 & 159.90 & 262.90 \\
August & 21.90 & 22.76 & 83.80 & 110.50 & 208.10 & 152.80 \\
September & 15.50 & 16.17 & 32.20 & 24.80 & 184.40 & 209.20 \\
Total $^{a}$ & 18.00 & 17.89 & 385.80 & 349.70 & 1163.70 & 1199.50 \\
\hline
\end{tabular}

${ }^{a}$ Precipitation and sunshine are monthly sums, while temperature is a monthly mean of daily means

The experiment was established as a two-factor, randomized block design consisting of three replications. Each plot was $10 \mathrm{~m}$ long and consisted of 12 rows with a $0.7-\mathrm{m}$ row spacing. The experiment involved four planting densities, i.e. 50,000, 60,000, 70,000, and 80,000 plants ha ${ }^{-1}$. Maize kernels were sown by hand on April 25th, 2014, at the same spacing across all replications via a planting density rope. The plant growth regulator 'Yuhuangjin' was applied evenly at the jointing stage $(20 \mathrm{~mL}$ of liquid 'Yuhuangjin' in $30 \mathrm{~kg}$ water was applied per hectare), whereas only water was applied for the control treatment (CK represents the water treatment used for comparisons, and $\mathrm{Y}$ indicates the 'Yuhuangjin' treatment. 5CK represents the treatment in which plants at a planting density of 50,000 plants $\mathrm{ha}^{-1}$ were subjected to the water treatment, and $5 \mathrm{Y}$ represents the treatment in which plants at a planting density of 50,000 plants ha $^{-1}$ were subjected to the 'Yuhuangjin' treatment. $6 \mathrm{CK}, 6 \mathrm{Y}, 7 \mathrm{CK}, 7 \mathrm{Y}, 8 \mathrm{CK}, 8 \mathrm{Y}$ and so on follow the same convention). The maize plants received $250 \mathrm{~kg}^{-1}$ diammonium phosphate, $75 \mathrm{~kg} \mathrm{ha}^{-1}$ urea, and $150 \mathrm{~kg} \mathrm{ha}^{-1}$ potassium sulphate at the seedling stage, and $300 \mathrm{~kg} \mathrm{ha}^{-1}$ of urea was topdressed at the jointing stage.

Two 4-m-long sections of consecutive rows were selected in each treatment to calculate the numbers of plants, ears number, barren stalks and barren tip. All the maize plants were harvested, and twenty ears were randomly selected for calculating the number of ears per row, number of kernel per row, 100-grain weight and theoretical yield of each treatment. The average value of the three replications was calculated.

\section{Measurement of SPAD values}

The SPAD values were measured using a PAM-2100 chlorophyll meter (Heinz Walz $\mathrm{GmbH}$, Eichenring 6.91090 Effeltrich, Germany). The degree of leaf senescence was considered the relative reduction in the SPAD value: degree of leaf senescence $=\left(\mathrm{SPAD}_{\mathrm{t} 1}-\mathrm{SPAD}_{\mathrm{t} 2}\right) / \mathrm{SPAD}_{\mathrm{t} 1} \times 100 \%$. Beginning at the onset of pollen shedding (July 29th), sampling was conducted at 4 p.m. every $10 \mathrm{~d}$. The ear leaf was placed in an ice box, transported to the laboratory, and maintained in a refrigerator at $-80^{\circ} \mathrm{C}$. On the following day, each physiological index was measured using the same part of the leaf that was washed and dried with absorbent paper. 


\section{Measurement of antioxidant enzyme activity}

To determine the antioxidant enzyme activity, fresh leaves $(0.5 \mathrm{~g})$ were homogenized by grinding with a mortar and pestle in $10 \mathrm{~mL}$ of ice-cold potassium phosphate buffer (KPB; $\mathrm{pH} 7.0)$ in an ice bath. The mixture was then centrifuged at $12000 \mathrm{rpm}$ for $20 \mathrm{~min}$ at $4^{\circ} \mathrm{C}$. CAT activity in the supernatant was determined in accordance with the methods of Aebi (1984). POD activity was assayed in accordance with previously described methods (Saba et al., 2012), with some modification. The change in absorbance at $410 \mathrm{~nm}$ was recorded during a 3-min period. One unit of POD activity was defined as an increase of $0.1 / \mathrm{min}$. SOD activity was assayed as described by Huang method (Huang et al., 2008). The reaction mixture was incubated for 10 min under fluorescent light, after which the absorbance at $560 \mathrm{~nm}$ was measured. The ascorbic acid in maize leaves was assayed in accordance with the method reported by Mukherjee and Choudhuri (1983).

\section{Measurement of Soluble protein}

Soluble protein contents within fresh leaf extracts $(0.1 \mathrm{~g})$ were quantified in (KPB) $(50 \mathrm{mM}, \mathrm{pH} 7.5)$. These extracts were filtered through four layers of cheese cloth and then centrifuged at $15500 \mathrm{rpm}$ for $15 \mathrm{~min}$ at $4^{\circ} \mathrm{C}$. The supernatant was collected and subsequently stored at $4^{\circ} \mathrm{C}$ for protein determination. The leaf soluble protein contents were measured via the protein dye-binding method of Bradford (1976); bovine serum albumin served as the standard.

\section{Measurement of biomass and yield}

To determine the biomass and yield, two consecutive four-meter lengths were selected for each process. The rows per ear, number of ear, kernels row, number of row and hundred grain weight were calculated. After harvest, 20 ears were selected to calculate the kernels row, number of row, hundred grain weight, and the theoretical yield. The biomass was determined by the drying method, and the stalks and grains were dried separately. Each process was repeated three times, and the results were averaged.

\section{Statistical analyses}

All the data are presented as the mean values of three replications. The data were collated using Microsoft Excel 2003 (Microsoft Corporation, Redmond, Washington, USA). Treatment effects on grain yield; yield components; plant height; dry weight; SOD, POD, and CAT activity; MDA content; and soluble protein contents were analysed in accordance with the principles of analysis of variance; the generalized linear model (GLM) package in SPSS 17.0 software (SPSS Inc. Chicago, Illinois, USA) was used.

\section{Results}

\section{Effects of 'Yuhuangjin' and planting density on maize yields}

The yield factors of maize include mainly the effective number of ears per unit area, grain number per spike and grain weight, among which ear per unit area is the most easily controlled. Therefore, increasing density is an effective way to obtain high yields. 
The results showed that, as the planting density increased, the grain number per ear and the 100-grain weight decreased, the effective number of ears increased, and the yield increased within a certain range (Abuzar et al., 2011; Li et al., 2015). Therefore, the tight coordination between the effective number of ears per unit area and the grain yield per plant is a key component of attaining high yields. Table 2 shows that the yield in the water treatment increased initially but then decreased as the planting density increased; the highest yield, i.e. $12346.40 \mathrm{~kg} \mathrm{ha}^{-1}$, occurred at a planting density of 70,000 plants ha ${ }^{-1}$. This value was $34.94 \%$ and $12.89 \%$ higher than the that in the $5 \mathrm{CK}$ and $6 \mathrm{CK}$ treatments, respectively, and reached an extremely high level, and this value was significantly higher $(9.58 \%$ higher) than that in the $8 \mathrm{CK}$ treatment. The barren stem ratio in the $7 \mathrm{CK}$ and $8 \mathrm{CK}$ treatment was $1.857 \%$ and $4.037 \%$ higher, respectively, than that in the $5 \mathrm{CK}$ treatment. These results indicated that increasing density would lead to a decrease in airflow and light transmission within the canopy, affecting the pollination characteristics of plants and resulting in lower production capacity per plant (Table 2).

Table 2. Effects of 'Yuhuangjin' application and plant density on maize yield components

\begin{tabular}{c|c|c|c|c|c|c}
\hline Treatment & $\begin{array}{c}\text { Plant density } \\
\left(\text { plants ha }^{-1}\right)\end{array}$ & $\begin{array}{c}\text { Effective number } \\
\left.\text { of ears (ears ha }{ }^{-1}\right)\end{array}$ & $\begin{array}{c}\text { Rows per } \\
\text { ear }\end{array}$ & $\begin{array}{c}\text { Kernels per } \\
\text { row }\end{array}$ & $\begin{array}{c}\text { 100-grain } \\
\text { weight }(\mathrm{g})\end{array}$ & $\begin{array}{c}\text { Theoretical yield } \\
\left(\mathrm{kg} \mathrm{ha}^{-1}\right)\end{array}$ \\
\hline \multirow{3}{*}{ Water } & 50,000 & 49428.57 & $16.05^{\mathrm{a}}$ & $33.95^{\mathrm{bc}}$ & $33.97^{\mathrm{a}}$ & $9150.31^{\mathrm{d}}$ \\
& 60,000 & 59714.29 & $15.93^{\mathrm{a}}$ & $35.58^{\mathrm{abc}}$ & $32.31^{\mathrm{a}}$ & $10937.00^{\mathrm{c}}$ \\
& 70,000 & 67894.29 & $16.39^{\mathrm{a}}$ & $33.89^{\mathrm{bc}}$ & $32.74^{\mathrm{a}}$ & $12346.40^{\mathrm{b}}$ \\
& 80,000 & 75857.14 & $16.00^{\mathrm{a}}$ & $31.50^{\mathrm{de}}$ & $29.47^{\mathrm{b}}$ & $11266.74^{\mathrm{c}}$ \\
\hline \multirow{3}{*}{ 'Yuhuangjin' } & 50,000 & 49571.43 & $15.80^{\mathrm{a}}$ & $33.95^{\mathrm{ab}}$ & $34.49^{\mathrm{a}}$ & $9711.98^{\mathrm{d}}$ \\
& 60,000 & 59857.14 & $15.95^{\mathrm{a}}$ & $33.50^{\mathrm{cd}}$ & $34.36^{\mathrm{a}}$ & $10989.10^{\mathrm{c}}$ \\
& 70,000 & 68085.71 & $15.45^{\mathrm{a}}$ & $36.50^{\mathrm{a}}$ & $34.61^{\mathrm{a}}$ & $13290.95^{\mathrm{a}}$ \\
& 80,000 & 76942.86 & $15.90^{\mathrm{a}}$ & $31.28^{\mathrm{e}}$ & $31.71^{\mathrm{ab}}$ & $11694.96^{\mathrm{bc}}$ \\
\hline
\end{tabular}

The 100-grain weight and yield were both converted to those at a $14 \%$ moisture level. The different letters indicate a significant difference $(\mathrm{P}<0.05)$ between treatments

Compared with that in the water treatment, the maize yield in the 'Yuhuangin' treatment increased but did not reach a significant level. The maximum maize yield (13290.95 $\left.\mathrm{kg} \mathrm{ha}^{-1}\right)$ occurred at a planting density of 70,000 plants ha ${ }^{-1}$, which occurred for both the water and 'Yuhuangjin' treatments. Under different planting densities, compared with those in the respective water treatments, the yields in the 5Y, 6Y, 7Y and $8 \mathrm{Y}$ treatments increased by $6.14 \%, 0.48 \%, 7.65 \%$ and $3.81 \%$, respectively. The 'Yuhuangjin' treatment had the best effect on increasing production of planted that were planted at a planting density of 70,000 plants $\mathrm{ha}^{-1}$. Therefore, the proper combination of 'Yuhuangjin' and planting density can increase yields (Table 2).

\section{Effects of chemical regulators and planting density on maize plant height and dry matter weight}

Table 3 shows that, in the water treatment, plant height increased gradually and the dry matter weight of individual plants decreased gradually as the planting density increased. The height of plants that were planted at a planting density of 80,000 plants ha ${ }^{-1}$ was $23.3 \mathrm{~cm}$ higher than that of plants that were planted at a planting density of 50,000 plants ha ${ }^{-1}$; however, the dry matter weight was $100.01 \mathrm{~g}$ lower. This result showed that an increase in the number of plants per unit area increased the plant 
height, reduced the dry matter weight and could greatly increase the risk of lodging. There are limits associated with trying to increase yields by altering the population structure.

Table 3. Effects of 'Yuhuangjin' application and plant density on maize height and dry weight

\begin{tabular}{|c|c|c|c|}
\hline Treatment & Plant density (plants ha-1) & Plant height $(\mathrm{cm})$ & Dry weight $(\mathrm{g})$ \\
\hline \multirow{4}{*}{ Water } & 50,000 & $305.00 \pm 5.00^{\mathrm{bcd}}$ & $354.79 \pm 36.27^{\mathrm{ab}}$ \\
\hline & 60,000 & $318.33 \pm 1.53^{\mathrm{ab}}$ & $303.95 \pm 59.18^{\mathrm{bcd}}$ \\
\hline & 70,000 & $310.33 \pm 4.51^{\mathrm{bc}}$ & $273.68 \pm 18.63^{\mathrm{de}}$ \\
\hline & 80,000 & $328.33 \pm 8.50^{\mathrm{a}}$ & $243.00 \pm 10.16^{\mathrm{e}}$ \\
\hline \multirow{4}{*}{ 'Yuhuangjin' } & 50,000 & $293.33 \pm 10.41^{\mathrm{d}}$ & $386.02 \pm 10.21^{\mathrm{a}}$ \\
\hline & 60,000 & $310.00 \pm 5.00^{\mathrm{bc}}$ & $329.85 \pm 21.24^{\mathrm{bc}}$ \\
\hline & 70,000 & $302.67 \pm 2.52^{\mathrm{cd}}$ & $295.19 \pm 22.13^{\text {cde }}$ \\
\hline & 80,000 & $314.33 \pm 14.36^{\mathrm{bc}}$ & $251.77 \pm 13.16^{\mathrm{de}}$ \\
\hline
\end{tabular}

The values are the means \pm standard deviations. The different letters indicate a significant difference $(\mathrm{P}<0.05)$ between treatments

The heights of plants in the 'Yuhuangjin' treatment were 3.83\% (50,000 plants ha' $\left.{ }^{-1}\right)$, $2.47 \%\left(60,000\right.$ plants ha $\left.{ }^{-1}\right), 2.62 \%\left(70,000\right.$ plants ha $\left.^{-1}\right)$ and 4.26\% (80,000 plants ha $\left.{ }^{-1}\right)$ lower than those in the water treatment, whereas the corresponding dry matter weights were $8.80 \%\left(50,000\right.$ plants ha $\left.{ }^{-1}\right), 7.86 \%\left(60,000\right.$ plants ha $\left.^{-1}\right), 8.51 \%\left(70,000\right.$ plants $\left.^{-1}\right)$ and $3.61 \%\left(80,000\right.$ plants ha $\left.^{-1}\right)$ higher. The 'Yuhuangjin' treatment somewhat reduced plant height, increased the maize dry weight and promoted the transport of more nutrients to the grain, which increased both plant lodging resistance and grain yields. In conclusion, the application 'Yuhuangjin' improved the physiological function of individual leaves of plants at a high planting density, resulting in a reasonable plant phenotype and increased production depending on individual performance (Table 3).

\section{Effects of 'Yuhuangjin' and planting density on ear leaf SPAD values after the pollen-shedding period}

Chlorophyll is an important substance involved in the absorption and transformation of light energy during photosynthesis in leaves. The chlorophyll content reflects the degree of leaf senescence, and the SPAD value reflects the leaf chlorophyll content. Therefore, in this experiment, changes in SPAD values were used to represent changes in chlorophyll contents. Table 4 shows that, during the process of leaf senescence, the SPAD values in the water treatment decreased as the planting density increased. Immediately after the pollen- shedding period began $(0 \mathrm{~d})$, the SPAD values in the 6CK, 7CK, and 8CK treatments were $11.16 \%, 17.59 \%$ and $20.28 \%$ lower, respectively, than those in 5CK treatment. In addition, compared with those at $0 \mathrm{~d}$ after pollen shedding, the SPAD values in the $5 \mathrm{CK}, 6 \mathrm{CK}, 7 \mathrm{CK}$ and $8 \mathrm{CK}$ treatments at $40 \mathrm{~d}$ after pollen shedding were $20.08 \%, 30.76 \%, 33.34 \%$ and $34.65 \%$ lower, respectively. The extent of the reduction in leaf SPAD values increased as the planting density increased, and the degree of leaf senescence increased.

Table 4 also shows that the SPAD values of the ear leaves treated with 'Yuhuangjin' also decreased after the pollen-shedding period, and compared with those in the water treatment, the SPAD values at different densities and during different periods in the 
'Yuhuangjin' treatment was higher. The SPAD values in the 5Y, 6Y, 7Y and 8Y treatments decreased by $18.52 \%, 16.54 \%, 12.30 \%$ and $16.71 \%$, respectively, from 0 to $40 \mathrm{~d}$ after pollen shedding. The SPAD values in the 'Yuhuangjin' treatment were higher than those in the water treatment, i.e. the values increased by $4.83 \%$ $\left(50,000\right.$ plants ha $\left.^{-1}\right), 19.16 \%\left(60,000\right.$ plants ha $\left.^{-1}\right), 26.12 \%\left(70,000\right.$ plants ha $\left.{ }^{-1}\right)$ and $22.00 \%$ (80,000 plants $\left.\mathrm{ha}^{-1}\right)$, at $40 \mathrm{~d}$ after pollen shedding (Table 4). In conclusion, the SPAD values of the ear leaves decreased as the planting density increased. The 'Yuhuangjin' treatment prolonged the functional period by delaying leaf senescence, allowing more nutrients to be transferred to the grain, resulting in higher yields. Under the experimental conditions, a planting density of 70,000 plants ha ${ }^{-1}$ resulted in optimal results.

Table 4. Effects of 'Yuhuangjin' application and plant density on ear leaf SPAD values measured at different periods after pollen shedding

\begin{tabular}{c|c|c|c|c|c|c}
\hline \multirow{2}{*}{ Treatment } & \multirow{2}{*}{$\begin{array}{c}\text { Plant density } \\
\text { (plants ha }\end{array}$} & \multicolumn{5}{|c}{ Days after pollen shedding } \\
\cline { 3 - 7 } & 50,000 & $0 \mathrm{~d}$ & $10 \mathrm{~d}$ & $20 \mathrm{~d}$ & $30 \mathrm{~d}$ & $40 \mathrm{~d}$ \\
\hline \multirow{3}{*}{ Water } & 60,000 & $68.5 \pm 2.4^{\mathrm{d}}$ & $63.4 \pm 3.0^{\mathrm{c}}$ & $59.1 \pm 3.9^{\mathrm{d}}$ & $58.3 \pm 1.8^{\mathrm{d}}$ & $52.4 \pm 4.0^{\mathrm{d}}$ \\
& 70,000 & $63.6 \pm 7.0^{\mathrm{e}}$ & $63.2 \pm 2.3^{\mathrm{c}}$ & $59.2 \pm 1.7^{\mathrm{d}}$ & $55.4 \pm 4.6^{\mathrm{de}}$ & $47.7 \pm 3.5^{\mathrm{e}}$ \\
& 80,000 & $61.3 \pm 6.2^{\mathrm{e}}$ & $59.3 \pm 3.6^{\mathrm{d}}$ & $53.0 \pm 1.3^{\mathrm{e}}$ & $53.7 \pm 4.2^{\mathrm{e}}$ & $45.5 \pm 9.0^{\mathrm{e}}$ \\
\hline \multirow{3}{*}{ 'Yuhuangjin' } & 50,000 & $82.7 \pm 9.5^{\mathrm{a}}$ & $78.4 \pm 1.3^{\mathrm{a}}$ & $71.2 \pm 3.3^{\mathrm{a}}$ & $68.2 \pm 2.3^{\mathrm{a}}$ & $67.3 \pm 2.1^{\mathrm{a}}$ \\
& 60,000 & $74.8 \pm 4.7^{\mathrm{bc}}$ & $66.1 \pm 6.8^{\mathrm{b}}$ & $63.6 \pm 3.1^{\mathrm{bc}}$ & $62.6 \pm 3.4^{\mathrm{bc}}$ & $62.5 \pm 1.2^{\mathrm{bc}}$ \\
& 70,000 & $68.6 \pm 6.2^{\mathrm{d}}$ & $68.3 \pm 4.7^{\mathrm{b}}$ & $65.2 \pm 1.9^{\mathrm{b}}$ & $64.3 \pm 3.4^{\mathrm{b}}$ & $60.1 \pm 5.1^{\mathrm{c}}$ \\
& 80,000 & $66.6 \pm 4.1^{\mathrm{d}}$ & $64.7 \pm 1.8^{\mathrm{bc}}$ & $62.5 \pm 1.6^{\mathrm{c}}$ & $60.9 \pm 1.3^{\mathrm{c}}$ & $55.5 \pm 3.4^{\mathrm{d}}$ \\
\hline
\end{tabular}

The values are the means \pm standard deviations. The different letters indicate a significant difference $(\mathrm{P}<0.05)$ between treatments

\section{Effects of 'Yuhuangjin' and planting density on ear leaf SOD activity after pollen shedding}

SOD is a protective enzyme in organisms that can catabolise $\mathrm{O}_{2}^{-}$into $\mathrm{H}_{2} \mathrm{O}$ and $\mathrm{O}_{2}$ and protect the biomembrane system. Table 5 shows that the SOD activity of the ear leaf in the water treatment decreased as the planting density increased. After the pollen-shedding period, the SOD activity initially decreased, followed by an increase and then a decreasing trend; the peak value occurred at approximately $20 \mathrm{~d}$ after pollen shedding. The peak values in the $5 \mathrm{CK}, 6 \mathrm{CK}, 7 \mathrm{CK}$ and $8 \mathrm{CK}$ treatments were 208.58, $178.89,169.49$ and $147.84 \mathrm{U} \mathrm{g}^{-1}$ fresh weight (FW), respectively. The change trend of SOD activity in the 'Yuhuangjin' treatment was similar to that observed in the water treatment. The maximum values of SOD activity measured in the 'Yuhuangjin' treatments were $6.83 \%(5 \mathrm{Y}), 6.17 \%(6 \mathrm{Y}), 27.87 \%(7 \mathrm{Y})$ and $23.42 \%(8 \mathrm{Y})$ higher than those measured in the corresponding water treatments (Table 5).

In conclusion, increasing density led to a reduction in SOD activity in the ear leaf, which would reduce the scavenging ability of superoxide ion free radicals, aggravate the destruction of cell structure and accelerate the process of leaf senescence. The SOD activity in the ear leaf was greater in the 'Yuhuangjin' treatment than in the water treatment, which played a positive role in delaying the process of leaf senescence. 
Table 5. Effects of 'Yuhuangjin' application and plant density on ear leaf SOD, POD, and CAT activities as well as MDA content after the pollen-shedding period

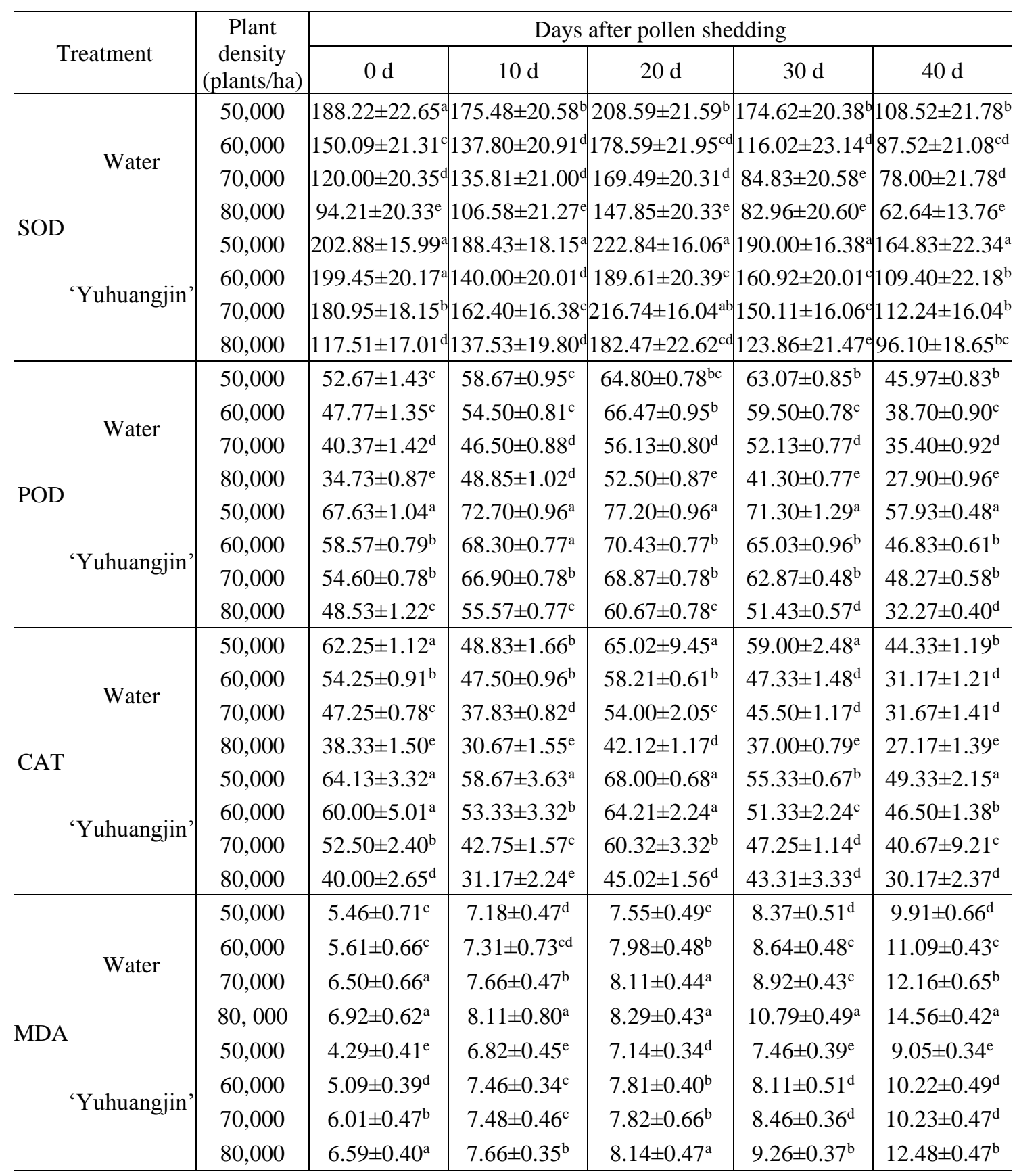

SOD, superoxide dismutase; POD, peroxidase; CAT, catalase; MDA, malondialdehyde. The same conventions are used below. The values are the means \pm standard deviations. The different letters indicate a significant difference $(\mathrm{P}<0.05)$ between treatments for each physiological and biological index

\section{Effects of 'Yuhuangiin' and planting density on POD activity in ear leaves after pollen shedding}

POD is another important enzyme involved in the plant protective enzyme system. POD can effectively eliminate the accumulation of peroxides in plants and reduce the 
degree of membrane lipid peroxidation, and this enzyme plays a positive role in maintaining leaf greenness. Table 5 shows that the POD activity in the water treatment decreased as the planting density increased; the activity increased initially but then decreased over time after pollen shedding. The maximum POD activity occurred at approximately $20 \mathrm{~d}$ after pollen shedding. The maximum POD activity values in the 5CK, 6CK, 7CK and 8CK treatments were 64.8, 66.47, 56.13 and $53.5\left(\triangle \mathrm{A} 470 \mathrm{~min}^{-1} . \mathrm{g}^{-}\right.$ $\left.{ }^{1} \mathrm{FW}\right)$, respectively. Table 5 also shows that the POD activity in the 'Yuhuangjin' treatment increased at a later stage, and compared with those in the water treatment, the maximum values in the 'Yuhuangjin' treatment were $21.14 \%\left(50,000\right.$ plants ha $\left.^{-1}\right)$, $7.28 \%\left(60,000\right.$ plants ha $\left.{ }^{-1}\right), 27.38 \%$ (70,000 plants ha $\left.{ }^{-1}\right)$ and $16.72 \%\left(80,000\right.$ plants ha $\left.^{-1}\right)$ higher. These results indicate that maximum POD activity occurred at a planting density of 70,000 plants ha ${ }^{-1}$ (Table 5).

In summary, an increase in planting density led to a reduction in POD activity, which can cause hydrogen peroxide $\left(\mathrm{H}_{2} \mathrm{O}_{2}\right)$ accumulations in the leaves, damage the cell membrane system, and reduce the ability of leaves to remain green. Spraying 'Yuhuangjin' can improve the canopy structure of a high-density population, increase both the POD activity in the ear leaves and the ability of leaves to remain green, and create favourable conditions for yield formation.

\section{Effects of 'Yuhuangjin' and planting density on CAT activity in ear leaves after pollen shedding}

CAT can promote the catabolism of $\mathrm{H}_{2} \mathrm{O}_{2}$ into molecular oxygen and water and can prevent the accumulation of $\mathrm{H}_{2} \mathrm{O}_{2}$ in cells. Table 5 shows that the CAT activity in the water treatment decreased as the planting density increased, and as the time after pollen shedding increased, an initial decrease followed by an increase and a subsequent decrease was observed; the peak value occurred at approximately $20 \mathrm{~d}$ after pollen shedding. The peak CAT activity values in the $6 \mathrm{CK}, 7 \mathrm{CK}$ and $8 \mathrm{CK}$ treatments were $10.47 \%, 16.95 \%$ and $35.22 \%$ lower, respectively, than the values in the 5CK treatment. The change trend of the 'Yuhuangjin' treatment was similar to that of the water treatment; the peak values were $4.62 \% \quad\left(50,000\right.$ plants $\left.\mathrm{ha}^{-1}\right), \quad 10.34 \%$ $\left(60,000\right.$ plants $\left.\mathrm{ha}^{-1}\right), 11.11 \%\left(70,000\right.$ plants $\left.\mathrm{ha}^{-1}\right)$ and $7.14 \%\left(80,000\right.$ plants ha $\left.{ }^{-1}\right)$ higher than those of the corresponding controls (Table 5).

Therefore, increasing planting density reduced the physiological function of the ear leaves, and the CAT activity decreased. However, the 'Yuhuangjin' treatment improved the CAT activity, which positive affected the greening ability of the leaves.

\section{Effects of 'Yuhuangiin' and planting density on the MDA content in the ear leaves after pollen shedding}

MDA is one of the end products of membrane lipid peroxidation. The MDA content reflects leaf senescence to a certain extent, and the accumulation of MDA can severely damage the subcellular structure of plants. Table 5 shows that, on the whole, the change trend of the MDA content in the water treatment was the same as that in the 'Yuhuangjin' treatment, i.e. an increase was observed in response to increasing planting density and time after pollen shedding. However, the 'Yuhuangjin' treatment caused a reduction in MDA contents, which, after $40 \mathrm{~d}$, were $8.71 \%\left(50,000\right.$ plants ha $\left.{ }^{-1}\right), 7.86 \%$ $\left(60,000\right.$ plants ha $\left.{ }^{-1}\right), 8.36 \%\left(70,000\right.$ plants $\left.\mathrm{ha}^{-1}\right)$ and $7.41 \%\left(80,000\right.$ plants ha $\left.{ }^{-1}\right)$ lower than those in the water treatment. The results showed that increasing planting density resulted in an increase both in membrane lipid peroxidation products and in leaf 
senescence. Less MDA accumulated in the 'Yuhuangjin' treatment than in the water treatment; in addition, the degree of membrane lipid peroxidation was lower in the former, and the leaf greenness retention ability was higher (Table 5).

\section{Effects of 'Yuhuangjin' and planting density on the soluble protein contents in ear leaves after pollen shedding}

Soluble protein enzymes in leaves include PEP carboxylase and RuBP carboxylase; changes in the contents of these enzymes reflect changes in enzyme activity. In addition, soluble protein contents are also associated with leaf metabolism, which is another important index of leaf senescence. Table 6 shows that, as planting density increased in the water treatment, the soluble protein contents in the ear leaves decreased. As time after pollen shedding increased, the soluble protein content increased initially but then decreased; the peak value occurred at approximately $10 \mathrm{~d}$ after pollen shedding. The soluble protein contents in the $6 \mathrm{CK}, 7 \mathrm{CK}$, and $8 \mathrm{CK}$ treatments were $20.72 \%, 23.37 \%$ and $27.11 \%$ lower, respectively, than those in the 5CK treatment. The results show that an increase in planting density can reduce light transmission within the canopy, resulting in poor environmental conditions for individual plants. In addition, increased planting density can reduce the soluble protein content, the activity of enzymes involved in $\mathrm{N}$ metabolism, and the yield of individual plants (Table 6).

Table 6. Effects of 'Yuhuangin' application and plant density on the soluble protein content of ear leaves after the pollen-shedding period

\begin{tabular}{c|c|c|c|c|c|c}
\hline \multirow{2}{*}{ Treatment } & \multirow{2}{*}{$\begin{array}{c}\text { Plant density } \\
\left(\text { plants ha }^{-1}\right)\end{array}$} & $0 \mathrm{~d}$ & $10 \mathrm{~d}$ & $20 \mathrm{~d}$ & $30 \mathrm{~d}$ & $40 \mathrm{~d}$ \\
\cline { 3 - 7 } & 50,000 & $33.02 \pm 1.88^{\mathrm{b}}$ & $36.54 \pm 1.45^{\mathrm{a}}$ & $30.16 \pm 1.00^{\mathrm{bc}}$ & $27.16 \pm 1.06^{\mathrm{b}}$ & $25.28 \pm 0.73^{\mathrm{a}}$ \\
& 60,000 & $24.33 \pm 0.15^{\mathrm{de}}$ & $28.97 \pm 2.22^{\mathrm{c}}$ & $23.02 \pm 0.74^{\mathrm{d}}$ & $22.47 \pm 1.25^{\mathrm{d}}$ & $19.85 \pm 1.01^{\mathrm{d}}$ \\
\multirow{3}{*}{ Water } & 70,000 & $25.84 \pm 0.93^{\mathrm{d}}$ & $28.00 \pm 1.73^{\mathrm{cd}}$ & $24.66 \pm 0.67^{\mathrm{d}}$ & $25.17 \pm 0.23^{\mathrm{c}}$ & $19.30 \pm 1.01^{\mathrm{d}}$ \\
& 80,000 & $22.64 \pm 0.91^{\mathrm{e}}$ & $26.63 \pm 0.73^{\mathrm{e}}$ & $21.13 \pm 1.00^{\mathrm{e}}$ & $20.17 \pm 1.18^{\mathrm{e}}$ & $16.54 \pm 0.69^{\mathrm{e}}$ \\
\hline \multirow{4}{*}{ 'Yuhuangjin' } & 50,000 & $36.51 \pm 1.31^{\mathrm{a}}$ & $35.69 \pm 1.02^{\mathrm{a}}$ & $39.67 \pm 1.13^{\mathrm{a}}$ & $35.43 \pm 0.52^{\mathrm{a}}$ & $26.48 \pm 1.27^{\mathrm{a}}$ \\
& 60,000 & $32.94 \pm 1.49^{\mathrm{b}}$ & $30.82 \pm 1.08^{\mathrm{b}}$ & $33.99 \pm 1.49^{\mathrm{b}}$ & $27.04 \pm 0.93^{\mathrm{b}}$ & $25.32 \pm 0.82^{\mathrm{a}}$ \\
& 70,000 & $30.01 \pm 0.94^{\mathrm{c}}$ & $29.73 \pm 0.66^{\mathrm{bc}}$ & $32.31 \pm 1.12^{\mathrm{b}}$ & $26.90 \pm 1.29^{\mathrm{b}}$ & $22.76 \pm 1.55^{\mathrm{b}}$ \\
& 80,000 & $27.02 \pm 0.96^{\mathrm{d}}$ & $26.45 \pm 0.81^{\mathrm{e}}$ & $28.61 \pm 1.10^{\mathrm{c}}$ & $24.57 \pm 2.02^{\mathrm{c}}$ & $20.57 \pm 0.87^{\mathrm{c}}$ \\
\hline
\end{tabular}

The values are the means \pm standard deviations. The different letters indicate a significant difference $(\mathrm{P}<0.05)$ between treatments

Table 6 also shows that, compared with the water treatment, the 'Yuhuangjin' treatment led to increases in soluble protein contents at each period; the maximum values occurred at approximately $20 \mathrm{~d}$ after pollination and were $8.57 \%$ $\left(50,000\right.$ plants ha $\left.{ }^{-1}\right), 17.35 \%\left(60,000\right.$ plants $\left.\mathrm{ha}^{-1}\right), 15.42 \%\left(70,000\right.$ plants ha $\left.{ }^{-1}\right)$ and $7.43 \%\left(80,000\right.$ plants $\left.^{-1} \mathrm{a}^{-1}\right)$ higher than those in the water treatment. The 'Yuhuangjin' treatment increased the metabolic activity of the maize ear leaf soluble proteins, which prolonged their functional period; increased the leaf greenness retention ability; and provided conditions for high yields. 


\section{Discussion}

Increased maize yield records have been reported in recent years, indicating that the average level of maize production in China may continue to improve (Zhao et al., 2006b). Increasing the planting density is the main cultivation practice to increase maize production. The results of this study showed that, when the planting density was between 50,000 and 70,000 plants $\mathrm{ha}^{-1}$, the yield increased as the planting density increased, and when the planting density exceeded 70,000 plants $\mathrm{ha}^{-1}$, the yield decreased as the planting density increased. Previous studies have shown that, under relatively high planting densities, an increase in the number of ears per unit area led to an increase in the number of grains per ear, which ultimately resulted in increased yields (Wei et al., 2017). The amount of dry matter is the material basis for the formation of grain yield, and the harvest index is an important factor affecting the yield (Gao et al., 2017). Increasing the planting density can significantly increase the amount of dry matter of groups and thus achieve the goal of increasing yield (Ogunlela et al., 1988). In the present study, the amount of dry matter per plant decreased as the planting density increased. The yield decreased after the planting density exceeded 70,000 plants ha ${ }^{-1}$. The harvest index can decrease in response to increase of planting density, and the efficiency of dry matter allocation from the stem to the grain can decrease, which results in relatively lower yields when the planting density is too high (Wei et al., 2017). Previous studies have shown that a lack of source material is the main limiting factor for yields at low planting densities; therefore, increasing the planting density can increase production. However, the source and sink materials increased simultaneously, but the proportion of increase was different under the high planting density, causing the relative shortage of sink tissue to be the main limiting factor for production. Currently, measures such as increasing the grain number, grain weight and harvest index represent the main mechanisms for increasing yield (Wang et al., 2013). Previous studies have shown that applications of chemicals could increase the harvest index, increasing the distribution of photosynthetic products to the grain, promoting the development of the ear, increasing both the number of grains per ear and the 100-grain weight, and increasing yields (Zhang et al., 2014; Otie et al., 2016). In this study, the 'Yuhuangjin' treatment significantly increased the amount of dry matter per plant and increased the yield of the population. The yield was highest at a planting density of 70,000 plants $\mathrm{ha}^{-1}$ in the 'Yuhuangjin' treatment.

The flowering stage of maize is a critical period for yield formation, but it is also the time during which the physiological function of leaves gradually decreases. The length of the leaf functional phase directly influences the formation of maize yield. During the senescence process, the gradual loss of leaf chlorophyll is the most definitive characteristic of leaf senescence, and leaf chlorophyll content and senescence are significantly negatively correlated (Mohr and Schopfer, 1995; Taiz and Zeiger, 2006). Research has shown that delayed leaf senescence, the retention of green leaves, and high photosynthetic rates can prolong the late growth stage of maize, significantly increasing yields (Huffaker, 1990; Ma and Dwyer, 1998). The results of this study showed that increasing planting density reduced leaf chlorophyll contents after pollen shedding. In addition, leaf senescence increased as the number of days after pollen shedding increased. Previous studies have shown that chemical control was beneficial for delaying the senescence of leaves in the middle and lower parts of the plant and for maintaining a relatively greater effective photosynthetic area during the middle and late stages of grain filling. The results of this study showed that 'Yuhuangjin' could increase 
leaf chlorophyll contents, delay leaf senescence and increase the accumulation of photosynthetic products, ensuring high yields.

Increasing the planting density is one of the key ways to increase yields. However, as the planting density of maize increases, competition for light, temperature, water and other environmental resources increases, which affects plant growth and development (Wei et al., 2017); this competition reduces stem thickness, increases plant height, reduces stem mechanical strength and increases the risk of lodging (Zhang et al., 2017). Compared with normal-height plants, dwarf plants exhibit better lodging resistance, which lays a good foundation for close planting and high yields (Ren et al., 2016). The results of the present study showed that, as the planting density increased, the height of the maize plants significantly increased, and the plants were prone to lodging. 'Yuhuangjin' applications significantly reduced plant height, increased lodging resistance and ensured maize yields under high planting densities, which is consistent with previous results (Zhang et al., 2017).

Since Harman hypothesized the involvement of free radicals in senescence in 1956, research on the mechanism of the active oxygen defence response in plants has expanded (Shen, 2001). Many studies have shown that, under normal and abnormal metabolic conditions, plants produce reactive oxygen free radicals; however, reactive oxygen species can be controlled, mainly by protective enzymes (e.g. SOD, POD, CAT) and non-protective enzymes, vitamin $\mathrm{C}$, and soluble proteins. When the metabolic balance is disturbed, free radicals accumulate in large amounts, leading to increased peroxidation of membrane lipids and increased MDA contents, which results in the destruction of the entire cell structure and function (Pan et al., 2006; Prochazkova and Wilhelmova, 2007). Previous studies have shown that leaf senescence is accompanied by the accumulation of reactive oxygen species and a decrease in antioxidant enzyme activities in cells (Prochazkova et al., 2001). Soluble protein contents are closely related to leaf function and senescence, which affect plant photosynthate accumulation and grain yields (Wang et al., 2016). The results of this study showed that increased planting density both led to a reduction in the activities of antioxidant enzymes (SOD, POD, CAT) in the ear leaves, an increase in MDA contents, and a decrease in soluble protein contents and accelerated leaf senescence. By regulating the balance of endogenous hormones, chemical controls can regulate plant growth and development, increase both the activity of plant protection enzymes and the soluble protein content, and improve plant adaptability to the environment, ultimately increasing crop yields (Wang et al., 2016). In the present study, 'Yuhuangjin' applications increased the activity of antioxidant enzymes, reduced the MDA content, increased the soluble protein content, increased the stay-green ability of the leaves and prolonged the functional period of the ear leaves, resulting in higher yields.

\section{Conclusion}

In a proper density extent, as the planting density increased, the 100-grain weight, rows per ear and number of grains per row decreased, whereas the barren stalk proportion and lodging risk increased. However, the increase in the effective number of ears per unit area compensated for the yield reduction caused by this density-induced stress. Under the premise of ensuring a specific density, 'Yuhuangjin' applications can reduce plant height, increase lodging resistance, shape a reasonable phenotype and delay leaf senescence to extend the functional period of the leaves, improve production 
conditions and increase production to a certain extent. Applications of chemical growth regulators and close planting at a reasonable density are therefore important ways for improving spring maize yields in Northeast China.

Acknowledgements. This work was supported by National Key Research and Development Program of China (grant no. 2016YFD0300103 and 2017YFD0300506), Heilongjiang Provincial Funding for National Key Research and Development Program of China (GX18B029), The "Academic Backbone" Project of Northeast Agricultural University (17XG23) and Postdoctoral Scientific Research Development Fund of Heilongjiang Province China (LBH-Q16031).

Conflict of Interests. Authors state no conflict of interests.

\section{REFERENCES}

[1] Abuzar, M. R., Sadozai, G. U., Baloch, M. S., Baloch, A. A., Shah, I. H., Javaid, T., Hussain, N. (2011): Effect of plant population densities on yield of maize. - Journal of Animal and Plant Sciences 21(4): 692-695.

[2] Aebi, H. (1984): Catalase in vitro. - Methods in Enzymology 105(105): 121-126.

[3] Andrade, F. H., Calvino, P. C. (2002): Yield response to narrow rows depends on increased radiation interception. - Agronomy Journal 94(5): 975-980.

[4] Andraski, T. W., Bundy, L. G., Brye, K. R. (2000): Crop management and corn nitrogen rate effects on nitrogen leaching. - Journal of Environmental Quality 29(4): 1095-1103.

[5] Bajguz, A., Hayat, S. (2009): Effects of brassinosteroids on the plant responses to environmental stresses. - Plant Physiology and Biochemistry 47(1): 1-8.

[6] Bradford, M. M. (1976): A rapid and sensitive method for the quantitation of microgram quantities of protein utilizing the principle of protein-dye binding. - Analytical Biochemistry 72(1-2): 248-254.

[7] Cao, C. Y., Li, W., Dang, H. K., Zheng, C. L., Ma, J. Y., Li, K. J., Wang, G. C., Zhang, S. G. (2013): Study on the influences of plant densities on yield, yield traits and canopy photosynthesis characteristics of summer maize. - Acta Agriculturae Boreali-sinica 28(S1): 161-166.

[8] Cao, Q. J., Gang, L., Diallo, L., Yang, F. T., Yao, L., Cui, J. H., Song, F. B. (2016): Effect of plant growth regulators on maize (Zea Mays L.) agronomic characteristics, stalk lodging and yield under high planting density in Northeast China. - Romanian Agricultural Research 33: 217-226.

[9] Chen, S. Q., Zhao, H. X., Yang, L. M., Du, X. D., Xue, Q. F., Jin, G. H., Zhou, T., Wang, C., Shan, L. L., Li, M., Wang, Q. Y. (2013): Preliminary study on regulate technique for resisting to lodging and high yielding cultivation of rice in cold region. - Acta Agriculturae Boreali-sinica 28(6): 159-165.

[10] Diallo, L., Cao, Q., Yang, F., Yang, Z., Cui, J., Gang, L., Dafaalla, T. I. M., Diarso, M., Ahmad, W. (2015): Seed priming effects of Yuhuangjin on spring maize. - The Journal of Animal and Plant Sciences 25(3): 747-754.

[11] Gao, J., Zhao, B., Dong, S. T., Liu, P., Ren, B. Z., Zhang, J. W. (2017): Response of summer maize photosynthate accumulation and distribution to shading stress assessed by using ${ }^{13} \mathrm{CO}_{2}$ stable isotope tracer in the field. - Frontiers in Plant Science 8: 1-12.

[12] Huang, R. H., Liu, J. H., Lu, Y. M., Xia, R. X. (2008): Effect of salicylic acid on the antioxidant system in the pulp of 'Cara cara' navel orange (Citrus sinensis L. Osbeck) at different storage temperatures. - Postharvest Biology and Technology 47(2): 168-175.

[13] Huffaker, R. C. (1990): Proteolytic activity during senescence of plants. - New Phytologist 116: 199-231. 
[14] Li, X. Y., Tang, Q. Y., Li, D. Q., Li, W. K., Li, H. L., Cai, Q. H. (2011): Effects of different plant densities on the photosynthetic-physiological characters and yield traits in spring maize grown on super-high yielding paddy field. - Acta Agriculturae Borealisinica 26(5): 174-180.

[15] Li, J., Xie, R. Z., Wang, K. R., Hou, P., Ming, B., Guo, Y. Q., Sun, L. Y., Zhang, G. Q., Zhao, R. L., Li, S. K. (2015): Changes in plant-to-plant variability among maize individuals and their relationships with plant density and grain yield. - Philippine Agricultural Scientist 98(1): 89-97.

[16] Lu, M., Liu, W. G., Yue, Y. H., Cai, Z., Wang, S. P., Zhang, H. W., Jin, M. H. (2011): Analysis on yield and relevant traits of maize varieties in Jilin province in the past twenty years. - Journal of Maize Sciences 19(5): 59-63.

[17] Ma, B. L., Dwyer, L. M. (1998): Nitrogen uptake and use of two contrasting maize hybrids in leaf senescence. - Plant and Soil 199(2): 283-291.

[18] Mohr, H., Schopfer, P. (1995): Plant physiology. - Springer-Verlag, Berlin, Heidelberg, Germany.

[19] Mukherjee, S. P., Choudhuri, M. A. (1983): Implications of water stress-induced changes in the levels of endogenous ascorbic acid and hydrogen peroxide in Vigna seedlings. Physiologia Plantarum 58(2): 166-170.

[20] Ogunlela, V. B., Amoruwa, G. M., Ologunde, O. O. (1988): Growth, yield components and micronutrient nutrition of field-grown maize (Zea mays L.) as affected by nitrogen fertilization and plant density. - Nutrient Cycling Agroecosystems 17(2): 189-196.

[21] Otie, V., Ping, A., John, N. M., Eneji, A. E. (2016): Interactive effects of plant growth regulators and nitrogen on corn growth and nitrogen use efficiency. - Journal of Plant Nutrition 39: 1597-1609.

[22] Pan, Y., Wu, L. J., Yu, Z. L. (2006): Effect of salt and drought stress on antioxidant enzymes activities and SOD isoenzymes of liquorice (Glycyrrhiza uralensis Fisch). Plant Growth Regulation 49(2-3): 157-165.

[23] Pan, S. G., Rasul, F., Li, W., Tian, H., Mo, Z. W., Duan, M. Y., Tang, X. R. (2013): Roles of plant growth regulators on yield, grain qualities and antioxidant enzyme activities in super hybrid rice (Oryza sativa L.). - Rice 6(1): 9.

[24] Pommel, B., Gallais, A., Coque, M., Quillere, I., Hirel, B., Prioul, J. L. (2006): Carbon and nitrogen allocation and grain filling in three maize hybrids differing in leaf senescence. - European Journal of Agronomy 24(3): 203-211.

[25] Prochazkova, D., Saiaram, R. K., Srovatava, G. C., Singh, D. V. (2001): Oxidative stress and antioxidant activity as the basis of senescence in maize leaves. - Plant Science 161(4): 765-771.

[26] Prochazkova, D., Wilhelmova, N. (2007): Leaf senescence and activities of the antioxidant enzyme. - Biologia Plantarum (Prague) 51(3): 401-406.

[27] Ren, B. Z., Li, L. L., Dong, S. T., Liu, P., Zhao, B., Yang. J. S., Wang, D. B., Zhang, J. W. (2016): Effects of Plant Density on Stem Traits and Lodging Resistance of Summer Maize Hybrids with Different Plant Heights. - Acta Agronomica Sinica 42(12): 18641872.

[28] Ren, B. Z., Liu, W., Zhang, J. W., Dong, S. T., Liu, P., Zhao, B. (2017): Effects of plant density on the photosynthetic and chloroplast characteristics of maize under high-yielding conditions. - Science of Nature 104(3-4): 12.

[29] Saba, M. K., Arzani, K., Barzegar, M. (2012): Postharvest polyamine application alleviates chilling injury and affects apricot storage ability. - Journal of Agricultural and Food Chemistry 60(36): 8947-8953.

[30] Shafi, M., Bakht, J., Ali, S., Khan, H., Khan, M. A., Sharif, M. (2012): Effect of planting density on phenology, growth and yield of maize (Zea Mays L.). - Pakistan Journal of Botany 44(2): 691-696.

[31] Shen, C. G. (2001): Plant senescence physiology and molecular biology. - China Agriculture Press, Beijing, China. 
[32] Shin, S., Lee, J. S., Son, B. Y., Kim, J. T., Kim, S. G., Kim, M. J., Kim, S. L., Kwon, Y. U., Baek, S. B., Woo, M. O., Bae, H. H. (2014): Effect of plant density on growth and yield of extremely late-planted korean sweet corn hybrids (Zea mays L.) for fresh market. - Journal of Crop Science Biotechnology 17(4): 289-295.

[33] Taiz, L., Zeiger, E. (2006): Plant physiology, $4^{\text {th }}$ edition. - Sinauer Associates Inc. Publishers, Sunderland, Massachusetts, USA.

[34] Tokatlidis, I. S. (2017): Crop adaptation to density to optimise grain yield: breeding implications. - Euphytica 213(4): 92.

[35] Wang, Y. H., Wang, K. R., Zhao, R. L., Wang, K., Zhao, J., Wang, X. M., Li, J., Liang, M. X., Li, S. K. (2013): Relationship Between the Source and Sink of Spring Maize with High Yield. - Scientia Agricultura Sinica 46(2): 257-269.

[36] Wang, Y. C., Gu, W. R., Xie, T. L., Li, L. J., Sun, Y., Zhang, H., Li, J., Wei, S. (2016): Mixed compound of DCPTA and CCC increases maize yield by improving plant morphology and up-regulating photosynthetic capacity and antioxidants. - Plos One 11: e0149404.

[37] Wei, S. S., Wang, X. Y., Zhu, Q. C., Jiang, D., Dong, S. T. (2017): Optimising yield and resource utilisation of summer maize under the conditions of increasing density and reducing nitrogen fertilization. - Science of Nature 104(11-12): 86.

[38] Xu, C. L., Gao, Y. B., Tian, B. J., Ren, J. H., Meng, Q. F., Wang, P. (2017): Effects of EDAH, a novel plant growth regulator, on mechanical strength, stalk vascular bundles and grain yield of summer maize at high densities. - Field Crops Research 200: 71-79.

[39] Xu, T. J., Lv, T. F., Chen, C. Y., Liu, Y. E., Zhang, Y. T., Liu, X. Z., Zhao, J. R., Wang, R. H. (2019): Effects of Plant Density and Plant Growth Regulator on Stalk Traits of Maize and Their Regulation. - Scientia Agricultura Sinica 52(4): 629-638.

[40] Zhang, Y. K., Sun, M., Zhang, X. J., Wu, J. P., He, Z. Y., Ma, Y. P. (2006): Study on close planting and nutrient improvement of maize. - Journal of Maize Sciences 14(3): 129-132.

[41] Zhang, Q., Zhang, L. Z., Evers, J., Werf, W. V. D., Zhang, W. Q., Duan, L. S. (2014): Maize yield and quality in response to plant density and application of a novel plant growth regulator. - Field Crops Research 164: 82-89.

[42] Zhang, W. Q., Yu, C. X., Zhang, K., Zhou, Y. Y., Tan, W. M., Zhang, L. Z., Li, Z. H., Duan, L. S. (2017): Plant growth regulator and its interactions with environment and genotype affect maize optimal plant density and yield. - European Journal of Agronomy 91: 34-43

[43] Zhao, M., Zhou, S. X., Cui, Y. H. (2006a): Research and application of plant growth regulators on maize in China. - Journal of Maize Sciences 14(1): 127-131.

[44] Zhao, M., Li, J. G., Zhang, B., Dong, Z. Q., Wang, M. Y. (2006b): The compensatory mechanism in exploring crop production potential. - Acta Agronomica Sinica 32(10): 1566-1573. 